Вероника Штранц-Никитина

Charles University in Prague

veronika.stranz-nikitina@ff.cuni.cz

ORCID: 0000-0002-1468-5595
Data przesłania tekstu do redakcji: 08.05.2020

Data przyjęcia tekstu do druku: 26.08.2020

\title{
Композиционная роль диалога в книге Чернобыльская молитва
}

Abstract: Stranz-Nikitina Veronika, Kompozicionnaâ rol'dialoga v knige Chernobyl'skaâ molitva (The Composition Role of the Dialogue in Chernobyl Prayer: A Chronicle of the Future). "Poznańskie Studia Slawistyczne" 19. Poznań 2020. Publishing House of the Poznań Society for the Advancement of the Arts and Sciences, Adam Mickiewicz University, pp. 321-347. ISSN 2084-3011.

The paper deals with some specific features of dialogism in the book Chernobyl Prayer: A Chronicle of the Future by the Belarusian Nobel Laureate Svetlana Alexievich. As the title implies the article investigates typology of the dialogue in the text which is based on the Bakhtin's analysis of the concept of the dialogue and polyphony. The article describes some principles of dialogism in relation to the composition of the text.

KeYwords: dialogue; dialogism; polyphony; stylistics; the composition of the text; Svetlana Alexievich

\section{1. Предпосылки исследования}

Понятие диалога уже со времен основоположников изучения диалогизма М. Бубера (1995, 2008), М. М. Бахтина (2002) и В.С. Библера $(1989,1991)$ принадлежит к ключевым концептам мышления о литературных текстах, и мы можем выбирать из целой палитры формулировок и концепций диалогизма, но даже если ограничиться только областью исследования диалога в отношении к тексту, необходимо упомянуть таких ученых, исследовавших данную проблематику, как Н. Д. Арутюнова (1981), А. В. Ахутин (2005), Д. Г. Богушевич (2000), А. Вежбицкая (1999), В. В. Виноградов (1981), Т. Г. Винокур (1993), В. Н. Волошинов (2000), Дж. Гамперц (Gumperz, 1982), П. Грайс (Grice, 1975), Т. ван Дейк (1989), Г. Кларк (Clark, 1990). А. А. Леонтьев (1979), Дж. Лич (Leech, 1983), Е. В. Падучева (1982), 
Дж. Серль (Searle, 1992), С. А. Аристов и И. П. Сусов (Аристов, Сусов, 1999), Д. Таннен (Tannen, 1994), рассматривавших проблему вербального общения и диалогизма с позиции формально-структурной, функциональной, эстетико-культурологической, с точки зрения коммуникативной лингвистики, анализа дискурса, прагматики, психолингвистики, теории общения, логико-семантического или конверсационного анализа языка, а также с точки зрения компьютерной лингвистики.

Неразрывно связанный с диалогическим принципом полифонический характер прозы С. Алексиевич также не остался незамеченным исследователями и уже был рассмотрен с самых разных точек зрения. Например, С. В. Романова (Романова, 2019) исследует проблему богооставленности и богоизбранности в свете особого советского язычества и катастрофы как жертвоприношения, посредством которого потом и осуществляется диалог с Богом. А. Карпушева (Karpusheva, 2017) рассматривает молитву у Алексиевич как полифонически организованный коллективный плач, в то время как для С. Сайни (2013) жанр молитвы - это прямой диалог с Творцом, т.е. одновременно и исповедь человека перед Богом, и покаяние за содеянное зло, и надежда на прощение и спасение. В противоположность этому для Ю. Обертрайс (Obertreis, 2018) голоса забытых маленьких людей постсоветского пространства, потерявших почву под ногами, отнюдь не обращены к Богу, а превращаются в мощное исторические свидетельство. Й. Линдблад (Lindbladh, 2008) также воспринимает полифоническое свидетельство как способ работы с памятью, но это способ вовлечения прошлого в настоящее, а полифоническая структура предстает как метафора настоящего времени, в котором совокупность голосов представляет гетерогенное, не единое прошлое и неизвестное будущее. Полифоничность, таким образом, манифестирует относительность хронотопа, многообразие перспектив вместо цепочки событий. Автор четко различает понятие диалогизма как проявление полифонии и противостоящий ему принцип диалога как явление потребительское, препятствующее развитию истинного диалогизма, т.е. эстетика полифонии противопоставляется диалогическому дискурсу. Впрочем, на этот вопрос имеются и другие точки зрения. О. Трухан (2012), несмотря на тот 
факт, что также видит в диалогизме Алексиевич диалог прошлого и будущего, т.е. переосмысление ответов на онтологический вопрос линейности времени при ориентации на другого, отказывается от оппозиции полифонии и диалогизма. Т. Гундорова (2005) придерживается мнения, что полилог здесь скорее связан с телесностью текста как категории важной для литературы постмодерна, а В. Волкова (2014) рассматривает диалог в постмодернистическом ключе еще шире - как интертекст культуры. К. Гурска (2017) воспринимает диалогизм Алексиевич как средство раскрытия истории человечества в виде совокупности частных историй отдельных людей, где автор выступает как средство передачи, посредник осуществления композиционного принципа ансамбля голосов, темы которого, обладающие своей неповторимой мелодией, необходимо понимать именно в музыкальном смысле. В подобном направлении в своем исследовании продвигается и Н. Сивакова (2014), акцентируя композиционную проблему присутствия автора в тексте как текстологическую категорию, проявляющуюся в ритме повествования, выраженном в пересечении мотивных элементов, управляющих динамикой развития сюжета. По мнению же О. Десюкевич (2017), полифонический текст выполняет функцию коллективной памяти, и книги Алексиевич имеют, таким образом, вертикальный контекст. Совершенно с иных позиций к рассмотрению диалогизма в текстах Алексиевич подходит Ю. Сеппяляйнен (2016). Проведя экокритический анализ книги Чернобыльская молитва, он приходит к выводу, что элементам экосистемы приписываются человеческие качества, а голоса ведут диалог не столько между собой, сколько с историей, политикой или культурой, так как герои пытаются понять, каково место человека в природе.

\section{1. Цели, методы и материал исследования}

Целью нашего небольшого исследования, однако, является не сопоставление имеющихся многочисленных теоретических концепций в области исследования диалогического принципа в текстах Алексиевич, а лишь попытка рассмотреть влияние диалогического принципа 
на организацию, композицию одного, конкретного текста. Точнее еще у́же, на практических примерах проанализировать и типологизировать (основываясь на подходе М.М. Бахтина) различные виды диалога в тексте книги Светланы Алексиевич Чернобыльская молитва, а также рассмотреть связь категории когезии текста с реализацией диалогического принципа в книге.

Наш анализ будет базироваться на бахтинском понимании диалога ${ }^{1}$ как модели мысли, языка, сознания, личности и общества в целом (находящей свое воплощение в художественном тексте). При работе с языковым материалом мы будем использовать описательно-аналитический метод с его основными компонентами: наблюдением, обобщением, интерпретацией и типологизацией.

Материалом для нашего исследования послужит книга Светланы Алексиевич Чернобыльская молитва, по собственному же определению Светланы Алексиевич Хроника будущегго. Хроника, в отличие от бесстрастного исторического документа, вмещает малое и великое, повествует об истории конкретных человеческих чувств, человеческих душ. По словам Елены Степановой (2020): „На сегодняшний день это наиболее полное документальное свидетельство чернобыльских событий - у Алексиевич особая манера работы, она передаёт рассказы практически без обработки". Однако нас интересует именно обработка, т.к. именно с ее помощью автору удалось остановить мгновения реальности, переплавить их в чрезвычайное по силе и единственное в своем роде по форме художественное произведение, на страницах которого реальные люди рассказывают о главных событиях своего времени и вместе с тем о том, чем жило их „я”, чем было для них их время. Разумеется, на ограниченном пространстве статьи мы не можем провести комплексный анализ композиции произведения и дать исчерпывающие ответы на обозначенные вопросы (это остается предметом дальнейших исследований), однако в наших силах подробнее рассмотреть один из главных аспектов организации текста - диалогический принцип и описать его функционирование в тексте.

${ }^{1}$ Наиболее полно концепция диалогизма раскрывается Бахтиным в книге Проблемы поэтики Достоевского (Бахтин, 2002). 


\section{2. Понятие диалога у Бахтина}

Для М. М. Бахтина „быть - значит общаться диалогически” (Бахтин, 2002, 280), причем „один голос ничего не кончает и ничего не разрешает. Два голоса - минимум жизни, минимум бытия” (Бахтин, 2002, 280), а это значит, что диалог является подлинным событием бытия и выступает как исходная фундаментально-экзистенциальная категория. Ведь если в языке заключается суть бытия, источник духовной энергии человека, он является одновременно средством общения, возможностью познания и способом выражения. Бахтин убежден, что человек обречен на ситуацию диалога, диалог предстает как актуальный процесс, как живое событие, потенциально бесконечное и незавершимое (Бахтин, 2002, 60). Как отмечает Г. В. Дьяконов (2006),

в системе воззрений М. М. Бахтина диалог выступает как универсальный способ человеческого бытия, двойственно-двуединая природа которого заключается в „нераздельности-неслиянности” Я и Другого, а также в органичной взаимосвязи и взаимодополнении внешней и внутренней интенциональности, внешнего и внутреннего диалога.

С точки зрения художественного дискурса это означает восприятие текста как воплощения социального, идеологического разноречия, потому что в нем сталкиваются разные точки зрения, разные смысловые позиции, разные голоса. А задача диалогической поэтики, - раскрыть диалогический механизм смыслопорождения в художественном тексте, показать, что смысл не передается автором, а конституируется, выстраивается, появляется на стыках, на границах, в процессе взаимодействия голосов автора, героев, читателя, критика (Macovski, 1997). По мнению Плехановой (2003), возникающая полифония характеризуется тем, что участники и сам диалог принципиально незавершимы. В художественном тексте диалогический потенциал языка испытывается в полной мере, до предела, где другость, субъект (а каждый участник диалога у Бахтина всегда воспринимается именно как субъект), истина, язык превращаются в Слово как последнюю смысловую инстанцию, за которой стоит личность и истина. 
Что касается определения диалогического слова, то диалогически направленным Бахтин считает слово, направленное на Другого, то есть самостоятельный голос героя, который является автором своей концепции мира. Такой герой, как мы уже упомянули, - субъект собственного слова, а не объект авторского. Или, говоря словами М. М. Бахтина, носителем диалогического слова является

герой, голос которого построен так, как строится голос автора в романе обычного типа. Слово героя о себе самом и о мире также полновесно, как обычное авторское слово; оно не подчинено объектному образу героя как одна из его характеристик, но и не служит рупором авторскому голосу. Ему принадлежит исключительная самостоятельность в структуре произведения, оно звучит как бы рядом с авторским голосом и особым образом сочетается с ним и с полноценными же голосами других героев (Бахтин, 2002, 11).

Именно такими нам видятся голоса-исповеди, составляющие Чернобыльскую молитву.

\section{2. Типы диалогов в Чернобыльской молитве}

Типы диалога, встречающиеся нам в Чернобыльской молитве, чрезвычайно разнообразны, ведь диалогизм является, как мы увидим далее, основным текстообразующим принципом произведения. В целях упорядочения имеющихся типов диалога, мы воспользуемся классификацией прозаического слова с точки зрения диалогизма / монологизма, разработанной М. М. Бахтиным $(2002,222)$ в книге Проблемы поэтики Достоевкого дополнив ее примерами из анализируемого текста.

Таблица № 1. Типология диалога в мире Чернобыльской молитвы

I. Прямое, непосред- Пожалуй, единственным примером данного типа можно в приблиственно направленное жении считать некоторые части исторической справки. Например: на свой предмет сло- „По данным наблюдений, 29 апреля 1986 года высокий радиациво, как выражение онный фон был зарегистрирован в Польше, Германии, Австрии, последней смысловой Румынии, 30 апреля - в Швейцарии и Северной Италии, 1-2 мая инстанции говоряще- во Франции, Бельгии, Нидерландах" (Алексиевич, 1997, 6). Хотя го

и они при ближайшем рассмотрении приобретают диалогический налет, благодаря взаимным отношениям между несколькими текстами исторической справки. 


\begin{abstract}
II. Объектное слово К данному типу можно отнести некоторые пассажи интервью (слово изображенного автора с самим собой, где появляется диалог автора-интервьюлица) с преобладани- ера и интервьюируемого. Например: „Признания повторялись, ем социально-типиче- и я сознательно не убирала эти повторы в книге. И, вообще, поской определенности второв встретится много" (Алексиевич, 1997, 26). Здесь автор-интервьюер и в равной мере интервьюируемый с двух разных позиций пытаются прийти к пониманию смысла повтора в книге. В целом данный тип в тексте чрезвычайно редок.
\end{abstract}

III. Слово с установ- Является явно преобладающим по сравнению с типами I и II. кой на чужое слово (двуголосое слово)

1. Однонаправленное двуголосое слово

а) Стилизация

Можно привести пример из Монолога одной деревни, где первый абзац служит своего рода стилистической визитной карточкой говорящих (что можно отметить по сравнению с намного более слабой насыщенностью стилистически маркированными элементами всего остального пространства голоса). ,-- Гостейки к нам... Добрые люди... Не ворожилось на встречу, [...] Никакого знака... Бывает, ладонь чешется - поздоровкаешься. А сегодня, ани, не ворожилось. Одно соловейка всю ночь пел - на солнечный день. Ой!” (Алексиевич, 1997, 38). Здесь перед нами стилизация деревенского говора, что особенно заметно на уровне лексики: диалектизмы ани, ворожить (в значении предвещать), простонародно-разговорное поздоровкаться, характерно фольклорные диминутивы гостейки, соловейка, однако большую роль играет и интонационная структура, специфическая для деревенской, народной речи мелодика.

б) Рассказ рассказчи- К данному типу в какой-то мере можно отнести все исповеди, ка (рассказ от первого так как почти каждый герой осознает себя в некотором роде раслица) сказчиком. Например, голос из „Детского хора: Мама с папой поцеловались, и я родилась. Раньше я думала, что никогда не умру. А теперь знаю, что умру" (Алексиевич, 1997, 205).

в) Необъектное слово В качестве примера можно привести статью Вместо эпилога: героя (носителя ав- „Киевское бюро путешествий предлагает поездки в город Черторских замыслов) нобыль и мертвые деревни... [...] Посетите ядерную Мекку" (Алексиевич, 1997, 223). Здесь ясно видна однонаправленная апеллятивность журналиста и в то же время ясно проглядывает авторское начало.

2. Разнонаправленное двуголосое слово

а) Пародия со всеми ее Присутствует как элемент построения многих исповедей. Особеноттенками но часто употребляется в отношении властей. Например: „По радио уже третий месяц: обстановка стабилизируется... Обстановка стабилизируется... Обстановка стаб...” (Алексиевич, 1997, 113). 
б) Всякая передача чу- Один из самых распространенных типов. Например, перемена жого слова с переме- акцента в сторону утрированного преувеличения: „Вокруг тогда ной акцента все говорили: умрем-умрем... К двухтысячному году белорусы исчезнут" (Алексиевич, 1997, 37). В сторону насмешливой жалости: „после одной-двух бутылок... Разговоры только о судьбе страны и об устройстве Вселенной. Споры о Горбачеве и Лигачеве. О Сталине. Великая мы держава или нет, победим или не победим американцев? [...] Ну, Чернобыль взорвался, но наш человек первым вырвался в космос! Понимаете, до хрипоты, до утра" (Алексиевич, 1997, 170). Или же в сторону пренебрежительного возмущения: „Но как это? Какой-то профессор, какие-то физики осмеливаются учить цека?” (Алексиевич, 1997, 192).

3. Активный тип (от- Наиболее широко распространенный тип, все его подтипы богато раженное чужое сло- представлены практически на всем пространстве анализируемого во) текста.

a) Скрытая внутрен- Голос расщепляется в себе сразу по двум направлениям. В следуюняя полемика щем примере им владеют одновременно две установки: желанности и преступности любви, а также два противоречивых желания вспомнить и навсегда забыть. „О чем я молюсь? Спросите меня: о чем я молюсь? Я не в церкви молюсь. Про себя... Я хочу любить! Я люблю! Я молюсь за свою любовь! А мне... [...] Вспоминать? Может, надо на всякий случай оттолкнуть от себя... Отодвинуть...” (Алексиевич, 1997, 192)

б) Полемически окра- „Я - человек своего времени, я - убежденный коммунист. Безопасшенная автобиогра- но нас нынче ругать... Модно... Все коммунисты - преступники" фия и исповедь (Алексиевич, 1997, 179). „Голос” вспоминает о себе в полемическом ракурсе контраста собственного представления о себе и предполагаемых разнообразных, но всегда враждебных чужих точек зрения.

в) Всякое слово В том же монологе „голос” многократно старается предвосхитить с оглядкой на чужое предполагаемую реакцию собеседника: „Другие молчат, а я скаслово жу... Вы пишете... Ну, не конкретно вы, а в газетах пишут - коммунисты обманывали народ, скрывали от него правду. Но мы должны были..." (Алексиевич, 1997, 179).

г) Реплика диалога К этому типу относятся все диалоги, передаваемые героями, например: „Я спросил: «Скажите, какой результат?»- «Не для вас». - «А для кого же?»" (Алексиевич, 1997, 37).

д) Скрытый диалог

Все монологи героев, по сути - скрытые диалоги, так как и при изъятии реплик автора-интервьюера, мы ясно видим отчетливую направленность двуголосого слова вовне. Например: „Первый страх? Первый страх с неба упал... Водой плыл... А некоторые люди и много кто были спокойные, как камни. Крестом побожусь!" (Алексиевич, 1997, 48). Конечно, диалог с автором здесь обычно только кладет начало диалогу более разветвленному, разнородному, разнонаправленному. 
Разумеется, сами по себе приведенные примеры, по причине невозможности цитации здесь более крупных отрезков текста, лежат всегда в плоскости одного голоса и приведены вне контекста своего естественного функционирования в тексте. Чтобы приблизить внутритекстовые контекстуальные связи, мы приведем более обширный пример межголосового диалога в следующей главе.

\section{1. Пример реализации диалогического принципа} на пространстве одного голоса

Приведем полностью один из голосов Чернобыльской молитвы (Алексиевич, 1997, 173-174) в качестве иллюстрации их диалогической природы и как пример использования диалогического принципа для интеграции и общей организации текста в целом. Забегая вперед отметим, что в исповеди преобладает слово с установкой на чужое слово, а именно отраженное чужое слово и разнонаправленное двуголосое слово. Причем диалогическое напряжение голоса высвечивает связи, которыми он прорастает сквозь целый текст, а также приоткрывает внутреннюю противоречивую, диалогическую сущность самого голоса.

Монолог об уродце, которого все равно будут любить.

Моя дочка недавно сказала: „Мама, если я рожу уродца, я все равно буду его любить”. Вообразите себе?! Она учится в десятом классе, у нее уже такие мысли. Ее подружки... Они все об этом думают... У наших знакомых родился мальчик... Ждали его, первый ребенок. Красивая молодая пара. А у мальчика рот до ушей, а ушек нет... Я не хожу к ним, не наведываюсь, как раньше, не могу, а дочка нетнет, да и забежит. Ей хочется туда, она то ли приглядывается, то ли примеряется... (Алексиевич, 1997, 173-174).

Исповедь начинается с введения героиней голоса Другого - ее дочки. Целый абзац - это полемическая конфронтация героини с этим введенным голосом, идеологическую установку которого героиня воспринимает с ужасом и возмущением. Причем передача чужого голоса происходит с заметным смещением акцента. В том же абзаце появляется реплика к автору интервьюеру („Вообразите себе?!”), выявляющая скрытый диалог. Здесь же героиней вводится установка подруг 
дочери, и героиня строит свое внутренне противоречиво расщепленное высказывание о семье знакомых с оглядкой на их Другое мнение. Голос дочери здесь перекликается с голосом Ларисы 3. из Монолога о старых пророчествах, которая как бы озвучивает ее будущее. „Такие, как она (о своем ребенке инвалиде Чернобыля), не живут, такие сразу умирают. Она не умерла, потому что я ее люблю” (Алексиевич, 1997, 76). Следующий абзац проникнут конфронтацией.

Могли бы уехать отсюда, но поразмыслили с мужем и отказались. Боимся. Мы все тут - чернобыльцы. Не пугаемся друг друга [...] Мы - с одной памятью... С одинаковой судьбой... А везде, в любом другом месте мы - чужие. Прокаженные. Все привыкли к словам: „чернобыльцы”, „чернобыльские дети”, „чернобыльские переселенцы"... Но вы ничего о нас не знаете. Вы боитесь нас... (Алексиевич, 1997, 173-174).

В данном отрывке с самого начала и до конца происходит полемическая конфронтация между установкой чернобыльцев - Нас и нечернобыльцев - Вас. Причем позиция последних выглядит невежественно агрессивной и жестокой. Те же слова героини диалогически сплетаются со словами Николая Калугина: „Ты хочешь быть как все, а уже нельзя. Ты не можешь" (Алексиевич, 1997, 36), который, обращаясь к себе, собственно, обращается и к Надежде Бураковой. В тех же словах героиня вступает в диалог также с Николаем Прохоровичем Жарковым из Монолога на два голоса, не только проговаривающим тот же конфликт (интересно отметить, что с использованием тех же значимых местоимений), но и нашедшим для себя возможное объяснение:

Мир разделился: есть мы - чернобыльцы и есть вы, все другие люди. Заметили? У нас здесь никто не акцентирует: я - белорус, я - украинец, я - русский. Все называют себя чернобыльцами..... „Мы - из Чернобыля”, „я - чернобыльский человек”... Как будто, это отдельный какой-то народ.... Новая нация... (Алексиевич, 1997, 112).

Не доказывайте обратное. Не убеждайте. Я это пережила... В первые дни... Схватила дочку и ринулась в Минск, к сестре... Моя родная сестра нас не пустила в дом, потому что у нее был маленький ребенок, кормила грудью. Вообразите себе? И мы ночевали на вокзале (Алексиевич, 1997, 173-174).

Здесь происходит скрытый диалог с автором-интервьюером, причем героиня сама забегает вперед, предвосхищая позицию автора, и говорит 
уже с оглядкой на его возможные возражения. В отрывке есть и диалогическая встреча пережившего отчаяние оставленности „голоса” героини с „голосами” других монологов, нашедшими помощь.

Маме моей до сих пор стыдно, что мы в своей „грязной” одежде, обуви ночью ввалились в чужую квартиру. Но нас приняли, накормили. Жалели (Алексиевич, 1997, 95).

Я удивляюсь теперь своим знакомым, они, конечно, боялись, не могли не бояться, уже ходили всякие слухи, но все равно сами мне предлагали: бери все, что надо. Бери! (Алексиевич, 1997, 13).

Сумасшедшие мысли приходили в голову... Куда нам бежать? Может, лучше покончить с собой, чтобы не мучиться... [...] Я смотрю на наших детей: куда бы они не поехали, они чувствуют себя чужими среди своих сверстников... В пионерском лагере, где моя дочь один год отдыхала, к ней боялись прикоснуться: „Чернобыльский ежик. Светлячок. Она в темноте светится" (Алексиевич, 1997, 173-174).

Происходит явственное расщепление голоса героини на два мучительно противоречивых, можно даже выделить две фразы, принадлежащие явно внутреннему диалогу („Куда нам бежать? Может, лучше покончить с собой, чтобы не мучиться"). Далее вводится прямая цитата чужой речи и диаметральным изменением акцента при его передаче.

Вот говорят - война... Военное поколение... Сравнивают... Военное поколение? Да оно же счастливое! У них была победа. Они победили! Это дало им мощную энергию жизни, если пользоваться сегодняшними терминами, сильнейшую установку на выживание. Они ничего не боялись. Хотели жить, учиться, рожать детей. А мы? Мы всего боимся... Боимся за детей... За внуков, которых еще нет... Их нет, а нам уже страшно... [...] У всех депрессия... Чувство обреченности. Чернобыль метафора. Символ. И наш быт, образ мышления... (Алексиевич, 1997, 173-174).

Героиня диалогически вводит в исповедь противоречащую ее точке зрения идеологическую установку Всех. „Голос” занимает определенно негативную позицию по отношению к господствующему подходу к осмыслению Чернобыля как войны. Героиня противопоставляет себя (вернее „Мы” чернобыльцев) точке видения военного поколения, где обнажает коренные различия. Она также продолжает полемику с молодым поколением, для которого сравнение с войной представляется точным. „Их детство - война, а мое - Чернобыль”, говорит, например, Катя П. (Алексиевич, 1997, 93). В этой точке монолог 
соприкасается с множеством других голосов, по большей части опровергая их мнение, например: „Как в войну... С чем еще сравнить?” (Алексиевич, 1997, 129). Или же соглашаясь: „Войну можно понять... А тут?” (Алексиевич, 1997, 128).

В другой раз думаю, что лучше бы вы о нас не писали. Тогда бы нас меньше боялись. Не говорят же в доме ракового больного о его страшной болезни. А в камере пожизненного заключения никто не вспоминает о сроке...

Надежда Афанасьевна Буракова,

жительница городского поселка Хойники (Алексиевич, 1997, 173-174).

Здесь происходит расщепление голоса героини на две внутренне диалогически направленные установки. Свидетельство принесено, но голос борется с пониманием неправильности своего поступка, противостоит сам себе.

Проведя анализ одного из голосов, мы не можем не согласиться с Плехановой (2003), что

диалогические отношения, которые пронизывают текст, имеют своеобразный характер. Они не сводимы ни к логическим, ни к лингвистическим, ни к психологическим, ни к механическим или к каким-либо иным отношениям. Это особый тип смысловых отношений, которые возникают между целыми высказываниями, за которым и стоят речевые субъекты, авторы данных высказываний.

Очевидно, что напряжение диалогических линий, прорастающее сквозь текст, не только связывает его, но и позволяет возникнуть новым, куда более объемным смыслам, появляющимся в точках соприкосновения силовых линий установок отдельных голосов, что и определяет своеобразие композиции текста.

\section{2. Диалог и когезия² текста}

Принимая во внимание существование многочисленных подходов к классификации и анализу текстовых категорий ${ }^{3}$, мы, однако, по

${ }^{2}$ Под термином когезия мы вслед за Гальпериным $(1981,74)$ понимаем все разнообразие возможных внутритекстовых связей.

${ }^{3}$ Например, Бабенко $(2008,42)$ применительно к художественным текстам выделяет 14 текстообразующих категорий, в то время как Бойгранде и Дресслер (Beaugrande, 
причинам объема статьи, ограничимся лишь рассмотрением такой опорной категории как когезия текста (как ее определяет Гальперин $(1981,74)$.

2.2.1. Первым средством реализации внутритекстовых связей является продуманная и основанная на диалогическом принципе членимость текста. Она способствует восприятию отдельных частей и их отрезков, как связанных между собой напряженными струнами диалогизма. Так, например, название текста накладывает отпечаток на способ интерпретации монологов и тем сближает их. Благодаря схеме можно наглядно представить систему архитектоники текста. Соположение отрезков текста таково, что композиция состоит из своего рода двух концентрических замыкающихся колец, охватывающих текст, авторского интервью и трех внутренних циклов. К первому кольцу относится историческая справка и заметка Вместо эпилога; ко второму - Два одиноких человеческих голоса. Три цикла представляют собой три главы, каждая из которых симметрически завершена хором.

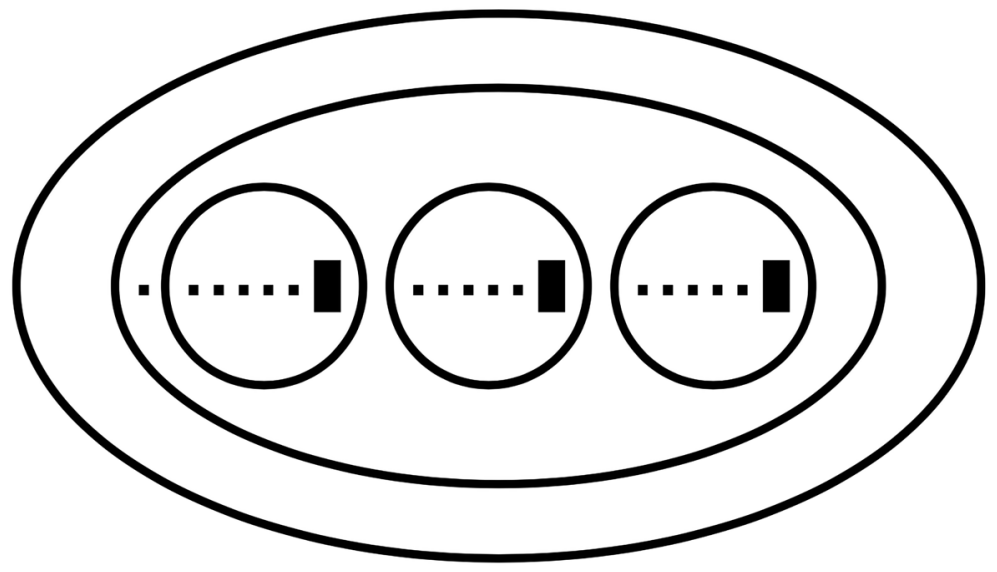

Схема № 1. Членение текста Чернобыльской молитвы.

Dressler, 1981) и Фатер (Vater, 1994) рассматривают в своих работах семь категорий текста. 
Так, Историческая справка состоит из четырех цитат, отграниченных друг от друга приведенным источником и отбивкой. Каждая из цитат - отдельный голос, причем последний из них двоится и распадается на два. Первая цитата из „Народной газеты” призывает „прорвать завесу неизвестности, окружающей Беларусь” (Алексиевич, 1997, 5). Этот призыв обращен вовне, следовательно перед нами диалогический ракурс голоса. На него откликаются следующие две цитаты, вкратце подающие необходимую фактографическую информацию о прошлом. Последняя цитата журнала „Огонек” посвящена размышлению о возможных будущих событиях и состоит из расщепленного голоса, пытающегося остаться в настоящем и одновременно приоткрыть возможное будущее. И Вместо эпилога представляет собой также газетную заметку - рекламное объявление с призывом „посетить ядерную Мекку” (Алексиевич, 1997, 223), она полемически ретроспективно обращена ко всем предыдущим голосам текста. Это внешнее композиционное кольцо отличается наименьшей диалогичностью, однако и здесь заметна направленность на Другого, в данном случае благодаря публицистическим характеристикам - на читателя.

Одинокие человеческие голоса представляют собой два рассказа от первого лица исповедального характера. Это значит, что они обращены напрямую к Богу (вспомним само название книги), однако предполагают присутствие исповедника, который также вступает в диалог. В них присутствуют как передача чужого слова с переменой акцента, так и внутренняя полемика, присутствуют формально оформленные и скрытые диалоги. Можно сказать, что однонаправленное слово полностью отсутствует, вытесненное двунаправленным. С формальной точки зрения Одинокие человеческие голоса членятся на отрезки, ритмически отбитые повторами.

Интервью автора с самим собой стоит как будто бы особняком, не входя ни в один из циклов, однако и не выходя за рамки ни одного из колец, что немаловажно. Ведь то, что интервью не обособлено от остальных монологов, помещает его в одну плоскость с ними. Автор в случае Чернобыльской молитвы такой же свидетель случившегося, как и другие „голоса”. Поэтому и выступает в качестве героя, отвечая на поставленные вопросы самому себе. Внешне данное 
интервью - это ярко формально-выраженное объектное слово и одновременно ясно видимый внутренний диалог, имеющий вопросно-ответную структуру.

Все три цикла отличаются подобным композиционным решением. Они состоят из нескольких „монологов”, количество которых постепенно увеличивается в последовательности 10, 12, 16 и завершающего хора. Здесь перед нами непосредственно встает вопрос о монологичности монологов. Нам представляется совершенно бесспорной диалогическая природа голосов уже хотя бы потому, что каждый из них построен по вышеприведенной схеме исповеди, то есть подразумевает направленность слова хотя бы на двух Других. Понятно, что в такой ситуации не может идти речи о монологической однонаправленности. Тем более, что основной исповедальный костяк «монолога» дополнен элементами стилизации, пародии, смещения акцентов при передачи чужих слов, диалогами внешними и внутренними, внутренней полемикой. И что особенно важно, голос героя строится с предварительной оглядкой на возможные внешние голоса. Поэтому дальнейшее разнообразное внутреннее членение монологов на соположенные части, абзацы, реплики, отграниченные паузами, повторами, вопросами и пр. является отражением их полилогической структуры. Рассмотрим скрытую диалогическую структуру монологов на примере взаимоотношения двух монологов, посвященных лжи государства: голоса Ирины Киселевой - журналистки (Алексиевич, 1997, 185-189) и голоса Владимира Матвеевича Иванова - бывшего первого секретаря Славгородского райкома партии (Алексиевич, 1997, 179-183).

С первых же слов рассказ-исповедь Владимира Матвеевича поражает своей чрезвычайной полемической направленностью, герой с первых же слов заявляет о своей жизненной позиции, как бы провоцируя воображаемого собеседника, который не замедляет появиться. „Все коммунисты - преступники”, „Это они, коммунисты виноваты..., Человек для них - песок, навоз истории”. Все это не слова Владимира Матвеевича, это - чужое, враждебное ему слово, слово противника, на которое герой заранее оглядывается и которое старается по мере возможности утрировать и довести до крайности: „Ату их! Ату”. Далее краткий полемический укол - укор в сторону бывших 
соратников: „Другие молчат, а я скажу...”. Но тут же фокус героя снова смещается, и в него попадает автор интервьюер: „Вы пишите... Ну, не конкретно вы, а в газетах пишут - коммунисты обманывали народ...”. Еще одна перестройка - коррекция фокуса высказывания (посредством выпущенной, однако незримо присутствующей, реплики автора) с автора интервьюера на некого журналиста вообще. Таким образом, и на столь малом пространстве текста явно виден диалог героя с различными, но одинаково враждебными ему чужими идеями, чужими словами. Владимир Матвеевич едва успевает поворачиваться в разные стороны, чтобы отбивать сыплющиеся на него удары. Удары эти, однако, уже через несколько страниц превращаются из видений первого секретаря в самостоятельную идею и озвучиваются громким голосом Ирины Киселевой.

А в колхозных конторах висят объявления, подписанные районными радиологами, что лук, салаты, помидоры, огурцы, - все можно есть. Все растет, все едят. Что они сейчас говорят эти районные радиологи? Секретари райкомов партии? Как оправдываются?

Последнее предложение как рефрен появляется в рассказе Киселевой три раза. Ирина Киселева задает свой вопрос по праву памяти, по праву пережитого, ее гневный голос тоже полемически направлен против слова противника (который ей не представляется таким уж затравленным). Что же отвечает, и в самом деле, как оправдывается Владимир Матвеевич?

Суть его идеи, его правды можно выразить последними словами его исповеди „Я - человек своего времени, я - не преступник”. Военный стереотип поведения делает для него ложь государства морально допустимой и просто необходимой: „Перед нами поставили задачу: не допустить паники. Паника, действительно, страшная вещь. Только во время войны так следили за сводками с фронта, как тогда за сообщениями из Чернобыля". С точки зрения героя в военной обстановке ответственность за принятые решения падает на высшее командование. На него же - ответственность за их исполнение: „Мы везли молоко с цезием на молокозаводы. Сдавали мясо. Косили сорокакюрийную траву. Выполняли планы... Я их выколачивал. Планы с нас никто не снимал...”. 
Однако, несмотря на всю уверенность в собственной правоте в голосе героя присутствует тень сомнения, в слишком уж безаппеляционных, бравурно-напористых интонациях проскальзывает ужас. И лазейки, оставляемые для себя тут и там: „Мы все были частью этой системы; Кому она нужна такая правда?” - выдают трагическую попытку героя оправдаться в диалоге перед самим собой. Наиболее напряженным местом исповеди можно назвать следующий отрывок, отличающийся приглушенной тональностью, приоткрывающей истинное лицо героя.

Если я - преступник, то почему моя внучка... Мое дитя... Она тоже больна... Дочь родила ее в ту весну, привезла к нам в Славгород в пеленочках. В коляске. Они приехали через несколько недель после взрыва на станции... Вертолеты летают, военные машины на дорогах... Жена просила: „Надо их отправить к родственникам. Увезти отсюда". Я был первым секретарем райкома партии... Я категорически запретил: „Что люди подумают, если я свою дочь с маленьким ребенком увезу?" [...] Если я преступник, то почему я убивал собственного ребенка? (Алексиевич, 1997, 173-174).

Искупает ли это страдание, оправдывает ли? Вот как соотносится с этим мучительным признанием идейная позиция Ирины Киселевой:

Я никогда их не оправдаю... Никогда!!! Только из-за одной той девочки... Она танцевала в больнице... Танцевала “полечку”... Ей лет девять. Так красиво танцевала... Через два месяца позвонила ее мама: “Оленька умирает! ” И у меня не хватило сил пойти в тот день в больницу. А потом уже было поздно. [...] Я никого не могу оправдать... (Алексиевич, 1997, 173-174).

Оба голоса, находящиеся в диалогическом отношении между собой не соположены автором прямо друг за другом, как вопрос и ответ, наоборот вопрошающий по преимуществу голос Ирины Киселевой следует за, по преимуществу ответствующим, голосом секретаря райкома партии, причем между ними расположен негативно настроенный по отношению к обеим точкам зрения третий анонимный голос (Алексиевич, 1997, 183-184). Это приводит к своего рода уравниванию веса двух идейных установок, создает острое напряженное противостояние, не давая при этом ни одной из них статуса последней правды. Данный эффект усилен и острым лингвостилистическим отличием третьего, размежевывающего голоса от приведенных двух, отличающихся культивированной литературностью и в условиях своей устности. Анонимный 
голос, напротив, характеризуется главным образом лексически сниженностью элементов: присутствием просторечий (напр., Горби), мата (напр., блядь), белорусизмов, свойственных деревенской речи (напр., цацка, сховать) и пр. Приведенный пример иллюстрирует создание напряженного диалогического отношения между отдельными голосами, благодаря чему автор добивается полноты звучания и жизни обоих голосов, в споре которых освещается в данном случае и ложь государства, и правда о человеке как таковом, и право на правду.

2.2.2. Следующее средство внутритекстовых связей - это ретроспекция в тексте. По своей сути рассказы «голосов»- это свидетельство о страшном опыте Чернобыля. Все они в той или иной мере возвращаются в свое прошлое в момент катастрофы или до него (феномен единого для всех Советского хронотопа: „В паспорте у меня и у детей записано - русские, а мы - не русские. Мы - советские! Но той страны, где я родилась, нет. Нет ни того места, что мы называли родиной, ни того времени, которое тоже было нашей родиной” [Алексиевич, 1997, 59]), вспоминают, судят себя сегодняшним взглядом, так работает механизм исповеди. А вместе с каждым голосом совершает „нырок” в прошлое и читатель. Только в отличие от героя, он, вынырнув и набрав воздуха, ныряет снова в ту же самую бездну, по-новому освещенную очередным голосом. В результате происходит как переакцентуация уже прочитанного, так и изменение восприятия на основе уже накопленной информации. Таким образом, с помощью ретроспекции происходит сцепление отдельных частей текста. Несмотря на то, что голоса связаны общей темой, хронотопом и многим другим, они не теряют самостоятельности и не „смазываются”. Нет, „это разные голоса, поющие различно на одну тему. Это и есть многоголосье, раскрывающее многообразие жизни и многосложность человеческих переживаний” (Бахтин, 2002, 53). Как видим, мы снова возвращаемся к диалогической основе средств внутритекстовых связей.

2.2.3. Перейдем к следующему средству когезии - к повтору. Из разнообразных функций этого приема остановимся лишь на его связующей функции в тексте. Приведем один из наиболее ярких примеров в этой области - использование образа войны как фундамента для построения образа Чернобыля. Употребление 139 слов из семантического гнезда война на 223 страницах текста уже говорит само за себя. Собственно 
лексический повтор типа: как в войну, вторая война, началась война, над войнами война, как с войны, в ту войну, настоямая война, атомная война, как во время войны, после атомной войны, это больше войны, это война, это не война, третья мировая война, война с невинными, как на войну, та же война - способен стать теми скрепами, на которых держится единство всего текста. К нему, однако, примыкает и повтор перифразного и ассоциативного характера. Например, относящийся к военным реалиям: „наркомовские сто граммов” (Алексиевич, 1997, 68), „они выпьют, воевавшие мужики, и говорят, я их слышал, до сих пор тоскуют...” (Алексиевич, 1997, 164). Или к военному хронотопу (в нашем примере персонифицированному Сталиным): „сталинский приказ” (Алексиевич, 1997, 164), „сталинская страна” (Алексиевич, 1997, 192), „тоскуют по сталинскому порядку” (Алексиевич, 1997, 202), „Сталина пережили” (Алексиевич, 1997, 40), „Я все время жду, что кто-то умный мне все объяснит... Как объясняют, просвещают меня насчет Сталина, Ленина, большевизма” (Алексиевич, 1997, 117), „в Кордильерах на скалах было высечено имя - Сталин!!” (Алексиевич, 1997, 146), „С юности я имел привычку все записывать. Когда Сталин умер - что происходило на улицах, о чем говорили" (Алексиевич, 1997, 157). Любопытно, что перифразные повторы тут же имеют тенденцию обрастать собственными повторами (принадлежащими, конечно, разным голосам). Например, в следующих случаях лишь первое предложение исповеди действительно принадлежит военным воспоминаниям: „У нее на руках маленький ребенок, месячный, шли по болоту, кругом каратели..." (Алексиевич, 1997, 99), „По сути дела, как в войну, мы действовали, как каратели” (Алексиевич, 1997, 88).

При помощи такой разветвленной сети повторов не только создается глубокий и завораживающий образ Чернобыля, но и происходит мощное и глубокое скрепление в определенной степени автономных участков текстов на пересечениях мотивных линий. Теперь обратимся к значению, которое имеет повтор для диалогизации текста. Приведем несколько примеров, взятых из разных мест текста и объединенных ключевым образом войны. Сразу же становится очевидно, что голоса вступают между собой в диалогические отношения, утверждая, соглашаясь, спрашивая, отвечая, пытаясь осмыслить и опровергнуть позицию Другого. 
Как в войну... С чем еще сравнить? (Алексиевич, 1997, 129).

Вот говорят - война... Военное поколение... Сравнивают... Военное поколение? Да оно же счастливое! У них была победа. Они победили! (Алексиевич, 1997, 174).

А тут слышу, что в одной деревне солдаты людей эвакуировали, а дед с бабкой остались. Перед тем днем, когда людей поднимали, вели в автобусы, они взяли коровку и подались в лес. Переждали там. Как в войну...( Алексиевич, 1997, 31).

„Как при немцах”, - сравнивают старые люди (Алексиевич, 1997, 115).

С войной сравнивать нельзя, не точно, а все сравнивают. Я ребенком пережил ленинградскую блокаду. Сравнивать это нельзя (Алексиевич, 1997, 109).

Таким образом, видно, что и повтор в тексте - явление, произрастающее из того же диалогического корня, что и большинство остальных средств когезии.

2.2.4. Последнее средство когезии, на котором мы остановимся, средство ассоциативное. Речь пойдет о развернутой метафоре как способе объединения целого текста. Исходным пунктом нам послужит название книги - Чернобыльская молитва. По определению молитва есть „беседа или разговор человека с Богом” (Будур, 2003). В данном же случае, по нашему мнению, перед нами исповедальный тип молитвы, который отличается обращением к своему прошлому и присутствием исповедника (автора), являющегося не прямым адресатом, а свидетелем исповеди. Образ исповедальной молитвы, отраженный в форме голосов (отступление автора, рассказ от первого лица, имеющий диалогический характер и т.п.), скрепляет текст. А ее диалогизм характеризуется одним общим камертоном трагичности и остроты высказывания, рождаемым в муках противоречия между невозможностью быть услышанным и необходимостью свидетельства. Если продолжить параллель с христианской молитвой, то перед нами не символ веры и не псалом 67, а скорее тихое „Господи верую, помоги моему неверию” (Мк. 9:24).

Метафора молитвы, развертываясь, дает нам возможность представить пространство книги как церковь, вмещающую в себя множество обращающихся к Богу душ, где отдельные молитвы объединяются в высшее единство и одновременно не утрачивают собственной неповторимой индивидуальности, то есть реализуется подлинная 
полифония. Подобное определение приводит Бахтин для характеристики мира романа Достоевского: „Если уж искать для него образ, к которому тяготеет весь этот мир, $[\ldots]$, то таким является церковь, как общение неслиянных душ, где сойдутся и грешники и праведники" (Бахтин, 2002, 34). Нам представляется, что это замечание целиком соответствует значению, которое имеет развернутая метафора молитвы в анализируемом нами полифоничном произведении, так как только такой уровень приближения к человеку дает возможность попытаться ответить на экзистенциальные вопросы, поставленные автором. Тем более, что и самой Алексиевич для характеристики собственного творчества и сущности Чернобыльской молитвы, была выбрана цитата из дневников Достоевского: „главный вопрос, на который я ищу ответ во всех книгах: сколько человека в человеке?” (Алексиевич, 2019).

\section{3. Заключение}

Так как диалогизм является основным текстообразующим принципом произведения, типы диалога в тексте Чернобыльской молитвы чрезвычайно разнообразны и основную роль здесь играет слово с установкой на чужое слово (двуголосое слово). А именно, три его типа: однонаправленное двуголосое слово, представленное стилизацией, рассказом от первого лица, необъектным словом героя - носителя авторского замысла; разнонаправленное двуголосое слово, представленное пародией со всеми ее оттенками и передачей чужого слова с переменой акцента; отраженное чужое слово, представленное скрытой внутренней полемикой, полемически окрашенной автобиографией и исповедью, словом с оглядкой на чужое слово, репликами диалога и скрытым диалогом.

Сополагая отдельные исповеди именно так, а не иначе, компонируя их в монологи и хоры, автор создает из отдельных осколков мозаику - картину мира после Чернобыля. Сами по себе осколки - голоса героев являются как бы цветными стеклышками, каждое из которых иначе преломляет проходящие сквозь него события, однако не дает общего целостного изображения. Целостность образа мира в книге 
возникает только под руками автора-композитора, складывающего отдельные стеклышки в неповторимый изображение, которого отнюдь не копирует действительность, а позволяет льющемуся сквозь него свету реальности отразить глубинную сущность взгляда на мир самого автора. Художественное целое произведения является результатом напряженного взаимодействия многочисленных и многообразных силовых диалогических линий, и их потрясающая сила сообщения заключается именно в совмещении неслиянности и единства.

Метафора молитвы, развертываясь, дает нам возможность представить пространство книги как церковь, вмещающую в себя множество обращающихся к Богу душ, где отдельные молитвы объединяются в высшее единство и одновременно не утрачивают собственной неповторимой индивидуальности, то есть на наших глазах в мире Чернобыльской молитвы реализуется подлинная полифония.

\section{Литература}

Алексиевич, С. А. (1997). Чернобыльская молитва. Москва: Остожье.

Алексиевич, С. А. (2019). Найти в человеке человека. „Psychologies” № 43. http://

www.psychologies.ru/standpoint/svetlana-aleksievich-nayti-v-cheloveke-cheloveka/. 7.08.2019.

Аристов, С. А., Сусов, И. П. (1999). Коммуникативно-когнитивная лингвистика и разговорный дискурс. http://homepages.tversu.ru/ ips/Aristov.htm. 5.08.2019.

Арутюнова, Н. Д. (1981). Фактор адресата. „Известия Академии наук СССР. Серия литературы и языка" т. 40, № 4, с. $356-367$.

Ахманова, О. С. (2004). Статья Диалог. В: Словарь лингвистических терминов.

Москва: УРСС.

Ахутин, А. В. (2005). Поворотные времена. Санкт-Петербург: Наука.

Бабенко, Л. Г., Казарин, Ю. В. (2008). Лингвистический анализ художественного текста. Москва: Флинта-Наука.

Бахтин, М. М. (2002). Проблемы поэтики Достоевского. В: Собрание сочинений, т. 6. Москва: Русские словари-Языки славянской культуры.

Библер, В. С. (1989). Идея культуры в работах Бахтина. „Одиссей” № 1, с. 21-59.

Библер, В. С. (1991). Михаил Михайлович Бахтин или поэтика культуры. Москва: Прогресс-Гнозис.

Библия. (1991). Откровение Иоанна Богослова, 8 Синодальный перевод. Москва, c. $10-11$.

Богушевич, Д. Г. (2000). Об эволючии образа языка в лингвистике. В: Интегративные тенденщии в современном социально-гуманитарном знании. Мате- 
риалы Международной научной конференции. Минск, 16-17 ноября 1999. Минск: МГЛУ, с. 125-132.

Бубер, М. (1995). Я И ТЫ. В: Два образа веры. Москва: Республика, с. 15-92. http// www.lib.ru/FILOSOF/BUBER/ihunddu2.txt. 12.08.2019.

Бубер, М. (2008). Изречённое слово. „Личность. Культура. Общество” № 2 (41), c. 19-27.

Будур, Н. В. (2003). Статья Молитва. В: Православный словарь. Москва: Олма-пресс.

Вежбицкая, А. (1999). Семантические универсалии и описание языков. Москва: Языки русской культуры.

Виноградов, В. Вч. (1981). Проблемы русской стилистики. Москва: Высшая школа.

Винокур, Т. Г. (1993). Говорящчий и слущающий. Варианты речевого поведения. Москва: Наука.

Волкова, В. Б. (2014). Концептосфера современной военной прозы. Автореферат диссертации на соискание ученой степени доктора филологических наук. Екатеринбург. http://elar.urfu.ru/bitstream/10995/24831/1/urgu1359s.pdf. 12.08.2019. На правах рукописи.

Волошинов, В. Н. (2000). Слово в жизни и слово в поэзии. В: Бахтин под маской. Москва: Лабиринт, с. 72-94.

Гальперин, И. Р. (1981). Текст как объект лингвистического исследования. Москва: Наука.

Горшков, А. И. (2000). Лекц̧ии по русской стилистике. Москва: Литературный институт им. Горького.

Гундорова, Т. (2005). Післячорнобильська бібліотека: Український літературний постмодерн. Киев: Критика.

Гурска, К. (2017). Творчество Светланы Алексиевич в контексте развития художественно документальной прозы (повесть „Цинковые мальчики”). „Вестник РУДН. Серия литературоведение. Журналистика” т. 22, № 2, с. 291-301.

Дейк, Т. А. ван (1989). Язык. Познание. Москва: Прогресс.

Десюкевич, О. И. (2017). Концеетууальная публицистика Светлань Алексиевич: кристаллизация жанра. „Медиалингвистика” № 2 (17), с. 31-40.

Дьяконов, Г. В. (2006). Концепциия диалога М.М. Бахтина - основа Экзистенциально-онтологической психологии. http//hpsy.ru/public/x2780.htm. 9.08.2019.

Книгин, И. А. (2006). Статья Диалог. В: Словарь литературоведческих терминов. Саратов: Лицей.

Костомаров, В. Г. (2005). Наш язык в действии, очерки современной русской стилистики. Москва: Гардарики.

Леонтьев, А. А. (1979). Понятие текста в современной лингвистике и психолингвистике. В: Психолингвистическая и лингвистическая природа текста и особенности его восприятия. Киев: Вища школа.

Майборода, Д. В. (2003). Статья Диалог. В: Новейший философский словарь. Минск: Издательство ВМ Скакун. 
Падучева, Е. В. (1982). Прагматический аспект связности диалога. „Известия Академии наук СССР, Серия литературы и языка" № 4, с. 305-313.

Плеханова, Т. Ф. (2003). Текст как диалог. Минск: МГЛУ. https//studylib.ru/ doc/3660134/plehanova-t.f.-tekst-kak-dialog-monografiya-t.f.plehanova. 5.08.2019.

Романова, С. В. (2019). Онтология и поэтика художественно-документальной прозы С. Алексиевич. „Вестник Пермского университета. Российская и зарубежная филология" т. 11, № 1.

Сайни, С. (2013). „Чернобыльская молитва: хроника будущего” С. Алексиевич. Проблема жанра. „Вестник Томского государственного университета. Культурология и искусствоведение” № 2 (10).

Сеппяляйнен, Ю. (2016). Экокритический анализ книги С.А. Алексиевич „Чернобыльская молитва: хроника будущего”. Дипломная работа, Университет г. Тампере.

Сивакова, Н. А. (2014). Цикл Светланы Алексиевич „Голоса утопии”: особенности жанровой модели. „Известия Гомельского государственного университета им. Ф. Скорины” № 1 (82), с. 148-151.

Статья Диалог. В: Энииклопедия эпистемологии и философии науки. http//philosophy.niv.ru/doc/encyclopedia/epistemology/articles/401/dialog.htm. 6.08.2019.

Степанова Е. (2020). Чернобыль: трагедия, подвиг, предупреждение. https://www. facebook.com/notes/елена-степанова/чернобыль-трагедия-подвиг-предупреждение/ 1836762766460978/. 14.04.2020.

Трухан, О. (2012). Діалогізм та полілогізм як засадничі приниипи сприйняття „жанру голосів” у „романі-свідченні” С. Алексієвич „Чорнобиль: хроніка майутнього” та романі Айрін Забитко „Невмите небо”. „Проблеми сучасного літературознавства" № 16, с. 366-377.

Филиппов, А. П. (2017). Последовательность двойных стандартов. https// om-saratov.ru/blogi/27-june-2017-i50296-posledovatelnost-dvoinyx-stand. 7.08.2019.

[Aleksievič, S. A. (1997). Černobyl'skaâ molitva. Moskva: Ostož'e.

Aleksievič, S. A. (2019). Najti v čeloveke čeloveka. „Psychologies” № 43. http//www. psychologies.ru/standpoint/svetlana-aleksievich-nayti-v-cheloveke-cheloveka/. 7.08.2019.

Aristov, S. A., Susov, I. P. (1999). Kommunikativno-kognitivnâ lingvistika i razgovornyj diskurs. http//homepages.tversu.ru/ ips/Aristov.htm. 5.08.2019.

Arutûnova, N. D. (1981). Faktor adresata. „Izvestiâ Akademii nauk SSSR. Seriâ literatury i âzyka" t. 40, № 4, s. 356-367.

Ahmanova, O. S. (2004). Stat'â Dialog. V: Slovar' lingvističeskih terminov. Moskva: URSS. Ahutin, A. V. (2005). Povorotnye vremena. Sankt-Peterburg: Nauka.

Babenko, L. G., Kazarin, Û. V. (2008). Lingvističeskij analiz hudožestvennogo teksta. Moskva: Flinta-Nauka.

Bahtin, M. M. (2002). Problemy poètiki Dostoevskogo. V: Sobranie sočinenij, t. 6. Moskva: Russkie slovari-Âzyki slavânskoj kul'tury. 
Bibler, V. S. (1989). Ideâ kul'tury v rabotah Bahtina. „Odissej” № 1, s. 21-59.

Bibler, V. S. (1991). Mihail Mihailovič Bahtin ili poètika kul'tury. Moskva: ProgressGnozis.

Bibliâ. (1991). Otkrovenie Ioanna Bogoslova, 8. Sinodal'nyj perevod. Moskva, s. 10-11 .

Boguševič, D. G. (2000). Ob èvolûcii obraza âzyka v lingvistike. V: Integrativnye tendencii v sovremennom social'o-gumanitarnom znanii. Materialy Meždunarodnoj naučnoj konferencii. Minsk, 16-17 noâbrâ 1999. Minsk: MGLU, s. 125-132.

Buber, M. (1995). A I TY. V: Dva obraza very. Moskva: Respublika, s. 15-92. http// www.lib.ru/FILOSOF/BUBER/ihunddu2.txt. 12.08.2019.

Buber, M. (2008). Izrečënnoe slovo. „Ličnost'. Kul'tura. Obŝestvo” № 2 (41), s. 19-27. Budur, N. V. (2003). Stat'â Molitva. V: Pravoslavnyj slovar'. Moskva: Olma-press.

Vežbickaâ, A. (1999). Semantičeskie universalii i opisanie âzykov. Moskva: Âzyki russkoj kul'tury.

Vinogradov, V. Vč. (1981). Problemy russkoj stilistiki. Moskva: Vysšaâ škola.

Vinokur, T. G. (1993). Govorâsij i slušaûsij. Varianty rečevogo povedeniâ. Moskva: Nuka.

Volkova V. B. (2014). Konceptosfera sovremennoj voennoj prozy. Avtoreferat dissertacii na soiskanie učenoj stepeni doktora filologičeskih nauk. Èkaterinburg. http://elar. urfu.ru/bitstream/10995/24831/1/urgu1359s.pdf. 12.08.2019. На правах рукописи.

Vološinov, V. N. (2000). Slovo v žizni i slovo v poèzii. V: Bahtin pod maskoj. Moskva: Labirint, s. 72-94.

Gal'perin, I. R. (1981). Tekst kak ob"ekt lingvističeskogo issledovaniâ. Moskva: Nauka.

Gorškov, A. I. (2000). Lekcii po russkoj stilistike. Moskva: Literaturnyj institut im. Gor'kogo.

Gundorova, T. (2005). Pislâčornobil's'ka biblioteka: Ukraïns 'kij literaturnij postmodern. Kiev: Kritika.

Gurska, K. (2017). Tvorčestvo Svetlany Aleksievič v kontekste razvitiâ hudožestvenno dokumental'noj prozy (povest' ,Cinkovye mal'čiki”). „Vestnik RUDN. Seriâ literaturovedehie. Žurnalistika” t. 22, № 2, s. 291-301.

Dejk, T. A. van (1989). Azzy. Poznanie. Moskva: Progress.

Desûkevič, O. I. (2017). Konceptual'naâ publicistika Svetlany Aleksievič: kristallizaciâ žanra. „Medialingvistika” № 2 (17), s. 31-40.

D'âkonov, G. V. (2006). Koncepciâ dialoga M. M. Bahtina-osnova Èkzistencial'noontologičeskoj psihologii. http://hpsy.ru/public/x2780.htm. 9.08.2019.

Knigin, I. A. (2006). Stat'â Dialog. V: Slovar' literaturovedčeskih terminov. Saratov: Licej.

Kostomarov, V. G. (2005). Haš âzyk v dejstvii, očerki sovremennoj russkoj stilistiki. Moskva: Gardariki.

Leont'ev, A. A. (1979). Ponâtie teksta v sovremennoj lingvisctike i psiholingvistike. V: Psiholingvističeskaâ i lingvističeskaâ prirodateksta i osobennosti ego vospriâtiâ. Kiev: Viŝa škola.

Majboroda, D. V. (2003). Stat'â Dialog. V: Novejšij filosofskij slovar'. Minsk: Izdatel'stvo VM Skakun. 
Padučeva, E. V. (1982). Pragmatičeskij aspekt svâznosti dialoga. „Izvestiâ Akademii nauk SSSR, Seriâ literatury i âzyka" № 4, s. 305-313.

Plehanova, T. F. (2003). Tekst kak dialog. Minsk: MGLU. https://studylib.ru/doc/ 3660134/plehanova-t.f.-tekst-kak-dialog-monografiya-t.f.plehanova. 5.08.2019.

Romanova, S. V. (2019). Ontologiâ i poètika hudožestvenno-dokumental'noj prozy S. Aleksievič. „Vestnik Permskogo universiteta. Rossijskaâ i zarubežnaâ filologiâ” t. 11, № 1. Sajni, S. (2013). „Černobyl'skaâ molitva: buduŝego” S. Aleksievič. Problema žanra. „Vestnik Tomskogo gosudarstvennogo universiteta. Kul'turologiâ i iskusstvovedenie" № 2 (10).

Seppâlâjnen, Û. (2016). Èkokritičeskij analiz knigi S. A. Aleksievič „Černobyl'skaâ molitva: hronika buduŝego". Diplomnâ rabota, Universitet g. Tampere.

Sivakova, N. A. (2014). Cikl Svetlany Aleksievič „, Golosa utopii”: osobennosti žanrovoj modeli. „Izvestiâ Gomel'skogo gosudarstvennogo universiteta im. F. Skoriny” № 1 (82), c. 148-151.

Stat'â Dialog. V: Ėnciklopediâ èpistemologii i filosofii nauki. http://philosophy.niv.ru/ doc/encyclopedia/epistemology/articles/401/dialog.htm. 6.08.2019.

Stepanova, E. (2020). Černobyl': tragediâ, podvig, predupreždenie. https://www.facebook.com/notes/ елена-степанова/чернобыль-трагедия-подвиг-предупреждение/ 1836762766460978/. 14.04.2020.

Truhan, O. (2012). Dialogizm ta polilogizm âk zasadničì principi sprijnâttâ „,žanru golosìv" u ,romanì-svidčennì" S. Aleksièvič „Čornobil': hronika majutn'ogo" ta romani Ajrì Zabitko „Nevmite nebo”. „Problemi sučasnogo literaturoznavstva” № 16, c. 366-377.

Filippov, A. P. (2017). Posledovatel'nost' dvojnyh standartov. https://om-saratov.ru/ blogi/27-june-2017-i50296-posledovatelnost-dvoinyx-stand. 7.08.2019].

Beaugrande, R.-A. de; Dressler, W. (1981). Einführung in die Textlinguistik. Tübingen: Niemeyer. https://doi.org/10.1515/9783111349305.

Clark, G. (1990). Dialogue, Dialectic, and Conversation: A Social Perspective on the Function of Writing. Carbondale: Southern Illinois University Press.

Grice, H. P. (1975). Logic and conversation. V: Syntax and semantics, vol 3. Eds. P. Cole, J. Morgan. New York: Academic Press, s. 41-58.

Gumperz, J. J. (1982). Discourse strategies. Cambridge. New York: Cambridge University Press. https://doi.org/10.1017/CBO9780511611834.

Karpusheva A. (2017). Svetlana Aleksievich's voices from Chernobyl: between an oral history and a death Lament. „Canadian Slavonic Papers” vol. 3-4, c. 259-280. https://doi.org/10.1080/00085006.2017.1381500.

Leech, G. N. (1983). Principles of Pragmatics. London: Longman.

Lindbladh, J. (2008). The Problem of Narration and Reconciliation in Svetlana Aleksievich's 'Testimony Voices from Chernobyl'. V: The Poetics of Memory in Post-Totalitarian Narration. Lund: CFE, Lund university, s. 41-54.

Macovski, M. (1997). Introduction. Textual Voices, Vocative Texts: Dialogue, Linguistics, and Critical Discourse. V: Dialogue \& Critical Discourse: Language, Cul- 
ture, Critical Theory. Ed. M. Macovski. New York-Oxford: Oxford University Press, s. 3-28.

Obertreis, J. (2018). Polyphonies on the ruins of sociallism: Svetlana Alexievich's work from the perspective of oral history. „Osteuropa: Zeitschrift fuer Gegenwartsfragen des Ostens" № 1-2 (68), s. 117-134.

Searle, J. R. (1992). Conversation Reconsidered. V: J. R. Searle et al. Searle on Conversation. Amsterdam: John Benjamins Publishing. https://doi.org/10.1075/pbns.21.

Tannen, D. (1994). Gender and Discourse. New York: Oxford University Press.

Vater, H. (1994). Einführung in die Textlinguistik. München: Fink. 